\title{
Akcióminőség vagy lexikai aspektus? II.* (Problémafelvetések a magyar akcióminőségek kapcsán)
}

\section{Az akcióminőség $\rightarrow$ lexikai aspektus átváltások első lépése: a származtatott aspektustípusok elkülönítése}

Dolgozatom I. részének 3. fejezetét azzal a konklúzióval zártam, hogy a 13 akcióminőség-típus két csoportra osztható, az akcióminőséggel szemben állított feltételeknek minden tekintetben megfelelő igekötő nélküli alakokra és az „akcióminőség” egyik-másik, esetleg több kritériumát nem teljesítő igekötősekre. Mivel fő célom az volt, hogy az akcióminőségeket az aspektuális osztályok keretén belül helyezzem el, két út állt előttem: az előbbiekre „nosztalgiából” megtartom a régi akcióminőség elnevezést, természetesen leszükítve a fogalmat az események időbeli lefolyására utaló tartalmakra, az utóbbiakat pedig integrálom az aspektuális osztályokba. A másik lehetőség az volt, hogy eltekintek a megállapított eltéréseiktől, és egységesen helyezem el öket az új taxonómiában.

Abban, hogy az első megoldást választottam, döntő szerepe volt Smith rendszerezésének, ő ugyanis a nézőponti és szituációs aspektuson kívül ismer úgynevezett

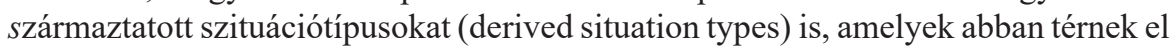
az első kettőtől, hogy szituációtípus-váltással hozhatók létre: „derived situation type is formed by a situation type shift" -'a származtatott szituációtípus szituációtípusváltással jeleníthető meg' (Smith 1991: 48). Kiefer az átértékelt jelzőt használja rájuk (Kiefer: 2006: 299), jómagam azért az előbbi terminust tartom megfelelőbbnek, mert jobban tükrözi a lényegüket, azt, hogy az öt aspektusfajta valamelyikéből hozhatók létre. A származtatott szituációknak három válfaja van, a szuperlexikális morfémákkal létrehozott lexikális fókuszos (János megirta a levelet $\rightarrow$ János befejezte a levélírást), az ismétléshez köthetö (János ebédel - cselekvés; János mindennap ebédel - Smith szerint habituális állapot), valamint a jelölt fókuszos helyzetek, amelyek az eseményeket mint állapotokat mutatják be: A hajó mozgásban van (Smith 1991: 48-52). Közülük bennünket a második érdekel. Az ismétlésnek két megtestesülését határozza meg Smith, a többszörös eseményü cselekvéseket (multiple-event activities) és a habituális állapotokat (habitual statives). A magyar nyelvészetben meghonosodott elnevezésük szerint az első az iteratív, az utóbbi a frekventatív jelzőt kapta. A frekventatív eseményeket Smith statikusnak, tehát állapotnak tartja (lásd az elnevezésüket) abból a megfontolásból, hogy egy megszakítás nélküli időszak általános jegyeként mutatnak be ismétlődő eseményszerüségeket, ezért annak minden intervallumára érvényesek a predikátumi szerkezetben foglaltak: Mindennap telefonálok / írok egy levelet / pihenek. Kieferrel egyetértve azt vallom, hogy az események ismétlődése csak dinamikus lehet (Kiefer i. m. 300), tehát inkább habituális cselekvésként azonosítanám a hasonló szituációkat. Anélkül, hogy elmélyülnék a kérdésben, meg kell jegyeznem, hogy a két szerző mást-mást ért habitualitáson: míg Smith az állapotokat is ide sorolja (János beteg), Kiefer kategorikusan kijelen-

* A tanulmány I. része megtalálható: Magyar Nyelvőr 144: 265-79. 
ti, hogy a „habituális olvasat elválaszthatatlan az iterativitástól” (i. m. 300), amit az állapotokban ő nem talál meg. Visszatérve a frekventatív szituációkra, főként időhatározókkal tudjuk megjeleníteni őket (ez a magyar nyelvre is igaz): Will wrote a report every week 'Will minden héten írt egy jelentést' (Smith i. m. 50).

A többszörös eseményü cselekvések, amelyeket Németh Boglárka többszöri eseményszerüségeknek nevez (Németh: 2012: 36) olyan események sorozatából állnak, amelyeknek végpontja tetszőleges. Kiinduló vagy aleseményük Smith szerint minden eseménytípus lehet, megítélésem szerint a magyar nyelvben elsődlegesen a szemelfaktívumok (nyit-nyitogat; int-integet), eredmények (felnéz-felnézeget) és csak ritkábban cselekvések: jár-járogat, száll-szálldos.

A nyelvek kifejezőeszközei közötti eltérésekre Smith is utal. Van, ahol - például az oroszban és a magyarban is - az események megsokszorozódását specifikus morfémák jelölhetik, máshol szintén kompozicionális aspektusfajtáról van szó, ami azt jelenti, hogy az egyszerü ige és az argumentumai által képviselt aspektuális értéket az NP-k, prepozíciók, adverbiumok stb. hozzáadásával származtatott aspektussá lehet alakítani, de előfordul az is, hogy az aspektuálisan többértelmü formák interpretációját pragmatikai elvek irányítják. A kétféle megjelenítés eltéréseit éppen Smith példái mutatják a legszemléletesebben: a The wheel revolved all day mondat ('A kerék egész nap pörgött') állítmánya a cselekvés többszöröződését az időhatározónak köszönheti az angolban, míg a magyar megfelelöje e nélkül is jelezni tudja a kerék mozgásának ismétlődését az ige inkorporálódott iteratív képzőjének köszönhetően, sőt szembeállítható vele az egyszeriséget jelölö forma is: 'A kerék pörgött egész nap' - A kerék megpördült. Az ismétlésre utaló morféma jelenlétével magyarázható az is, hogy a magyar anyanyelvü beszélő A fiú kopogott az ajtón mondat által leírt szituációban inkább a kopogás többszöriségét feltételezi, míg az angol számára a mondat határozója jelzi egyértelmüen az ismétlést: Guy repeatedly knocked at the door ('A fiú újra és újra kopogott az ajtón').

\subsection{Származtatott aspektusfajták a magyar nyelvben}

Noha Smith leírásában a származtatott aspektusfajták nem játszanak központi szerepet, kidolgozottságuk sem teljes, arra alkalmasnak bizonyultak számomra, hogy a Kiefer-féle 13 akcióminőség-típusból leváltakat azonosítsam velük. Ehhez összegyüjtöttem azokat a jellegzetességeket, amelyeket Smith ezekhez az aspektusfajtákhoz rendelt. Jelzem, hogy a cselekmény $\rightarrow$ teljesítmény átváltással nem származtatott szituációt hozunk létre, mert ez az átváltás a lexikális aspektusok szintjén megy végbe (János írja a levelet $\rightarrow$ János megírja a levelet). A származtatott aspektus tehát:

1. az öt aspektuális osztály „fölötti” kategória;

2. meghatározott aspektuális jegyekkel bíró kiinduló szituációból eredeztethető;

3. az aspektuális érték megváltozása vagy módosulása az alapige jelentését érinti. 
A fenti feltételeknek nemcsak az ismétléssel összefüggő frekventatív, iteratív csoportok felelnek meg, de a duratív-deminutív, valamint a delimitatív alakok is. Vizsgáljuk meg részletesen a sajátosságaikat.

\subsubsection{Iteratív, frekventativ aspektusok}

Van kiinduló, meghatározható aspektust képviselő szituációjuk (felnéz, nyit, üt), amelyből az új létrejön: fel-felnéz, nyitogat, ütöget. Mivel Kiefer sokat idézett munkájában kimerítően taglalja őket (2006: 150-62), írásából itt csak azt emelem ki, hogy két egymástól nehezen megkülönböztető jelentésről van szó, de az iteratívumok inkább a rendszeres ismétlődésre utalnak, a frekventatívumok a rendszertelenre. A frekventatívumok jelölöi lehetnek szintaktikai elemek (határozók: hébe-hóba, gyakran, mindennap), az igekötők megismétlése (meg-megáll, fel-felnéz, el-elnéz). Az iteratívumokhoz kizárólag a -gAt képzőt rendeli (nyitogat, ütöget), amely pillanatnyiságot tükröző, igekötőtlen alapigékkel tölti be jelen szerepét: nyitogat, integet, csukogat. A szóba jöhető alapigék családja nem lehet túl nagy, Kiefer is csak néhány példát sorol fel, azok sem mind punktuális jegyüek: az int, ver, nyit, csuk, ráz, lép, emel közül a nyelvérzékem szerint a ver, ráz konstitutív ismétlésre utalnak, az emel pedig duratív cselekvés, ahogy a máshol említett csókolgat, ölelget tövei is. Még ha hozzátesszük, hogy a mozzanatos -int markert tartalmazó igéket szintén - $g A t$ képzővel látjuk el (bólintgat, legyintget, hörpintget, kacsintgat), akkor sem kapunk népes tömörülést. (Papp Ferenc szóvégmutató szótárában csak 23 ilyen formát tudtam összeszámolni [Papp 1969]). A nem túl széles kapcsolódási lehetőségeken túl az azonos funkciójú - $d O s$ is kétségbe vonja a - $g A t$ kizárólagos iteratív képző voltát: a - $d O s$ húsznál több származékban van jelen, így akár „teljes jogú” iteratív képzőnek is nevezhetjük: vagdos, rugdos, sugdos, csókdos, nyaldos, szálldos, dugdos, kapdos, csapdos, mardos, szurdos, repdes, tépdes, csipdes, nyeldes, verdes, köpdös, lökdös, pökdös, szökdös, öldös. (Az alapigék szemantikailag a testrészek, kéz, láb, száj cselekvéseihez köthetők.)

Megjegyzem, a hangutánzó és fiktív tőhöz kapcsolódó - $O g$ a gyakoriságát tekintve felülmúlja mindkét képzőt, de - mint ahogy az I. rész 2.3 részében megállapítottam - inkorporálódott egysége az igejelentéseknek, következésképpen ezekre a formákra a cselekvések osztályának ,iteratív mozzanatú cselekvések” alosztályát lehet létrehozni. Az iteratív mozzanatú cselekvések a cselekvésekkel (tanul, ül, olvas) megegyezően atelikus duratív jegyekkel bírnak, de esetükben a hasonló vagy azonos cselekvésmozzanatok - amelyek létére morfológiai szerkezetük emlékeztet egy folyamattá válnak. Az -int, -An mozzanatos képzős lexémákat (koppan, cseppen, legyint) a szemelfaktívumok közé helyezem.

Mint ahogy volt róla szó, abban, hogy milyen aspektuális alaposztályba helyezhető az események megsokszorozódása, eltérnek a nézetek: Smith állapotként fogja fel öket, Kiefer az imperfektív szemléleti aspektushoz rendeli őket, jómagam, minthogy az aspektualitás másik, magasabb szintjéről van szó, eltekintek az alaposztályokba történő ,visszaváltástól”. 


\subsubsection{Duratív-deminutiv aspektus}

Parafrázisa alapján 'az igében kifejezett cselekvés csökkent intenzitással történő végzését' adja vissza, vagyis kiinduló igéje a cselekvések osztályát alkotja. Termékenynek tűnő képzésmód: ,a deminutív akcióminőség minden duratív igekötőtlen cselekvésigéből képezhető” (Kiefer 2006: 162). Ezt csak azzal egészítem ki, hogy a kapcsolódásának mindössze a szemantikai összeférhetetlenség szabhat gátat: a gyors, de tartós mozgások, történések intenzitásának csökkentése például értelmetlen lenne, mivel jelentésük alapelemétöl fosztaná meg őket a morféma: *sietget, *loholgat, *roboggat, *trappolgat. A hangutánzó és fiktív tövekhez ragasztott - Og szintén kizárja az intenzitáscsökkenést (*pityeregget, *nyafoggat), ami azt bizonyítja, hogy nem klasszikus duratív cselekvések (az iteratív mozzanatú cselekvések alkategória létrehozása az előző alfejezetben máris indokoltnak tünik). Teljesítményekből, valamint eredményekből szintén nem hozható létre, mert a végpont, kulminációs pont elérése szemantikailag kizárja a cselekvési folyamat középpontba állítását: *Délután elolvasgattam a cikket. Morfológiai jelölője a poliszemantikus, iteratív, frekventatív markerként is funkcionáló - $g$ At. A két funkció elkülönítése sokszor pragmatikai tényezők bevonásával lehetséges. A János nyáron festeget mondatban jelölhet rendszertelen ismétlödést, a Délután festegettem predikátuma pedig csökkent intenzitással történt cselekvésre utal.

\subsubsection{Delimitatív aspektus}

Az igetípus származtatott aspektusként való értelmezése hosszasabb indoklást igényel. A delimitatív jelző mai tudásunk szerint azokra a perfektív procedurális igékre vonatkozik, amelyek a cselekvés rövid vagy meghatározatlan időperiódusban történő lefolyására utalnak: eljátszik 'bizonyos ideig játszik'. Kizárólagos morfológiai jelölöje az el-. Sajátos aspektuális viselkedésü igecsoport, mivel igekötős igék alkotják ugyan, de nem telikus szituációkat ír le, amit az $x$ idö alatt teszttel való összeférhetetlensége igazol: *A kisgyerek egy óra alatt eljátszott. Az alapigéinek morfológiai felépítése háromféle lehet: a legnépesebb tömörülést azok a derivátumok képezik, amelyekben duratív-deminutív képzős tőhöz csatlakozik az el-: eljátszogat, eliddogál, elálldogál, eléldegél, elborozgat, elsörözget, elszundikál, elszunyókál. Második csoportjuk tagjainak egyszerü alapszava duratív cselekvés: elénekel, elrajzol, elrepül, ellakik. Általános, hogy ezek is duratív-deminutív képzőt kapnak, vagyis az 1-2. csoport tagjai átválthatók egymásba: elrajzol - elrajzolgat, elénekel - elénekelget. Kisebb hányadukat teszik ki az fiktív tövü iteratív formák: elandalog, elcsavarog, elnyammog, eltántorog, eltöpreng. A három típus közös jegyeként kell kiemelni intranzitív voltukat: az elsőben néhány kivételtől eltekintve az alapigék eleve tárgyatlanok, a harmadikban úgyszintén. A második alapigéi tárgyasak (énekel, rajzol), mégsem engednek meg argumentumként belső tárgyi határolót ebben a szerepben: elolvasta a könyvet (telikus teljesítmény). A származtatott jelző megkövetelte aspektuális módosítás, váltás feltételének azért felel meg, mert atelikus cselekvési szituációkból hoz létre atelikus, de terminatív (időhatárokhoz kötött) cselekvést. A terminativitást én az orosz aspektológiában ismert módon (Glovinskaja 1982; Bondarko 1986) a behatároltság legáltalánosabb megjelenésmódjának tekintem. 


\section{Akcióminőség $\rightarrow$ lexikai aspektus átváltások}

Nézzük azokat az eseteket, jelesül az 5-13. pontok „akcióminőségeit”, amelyeknél megkérdőjeleződtek az alapfogalmuk ismérvei. A két szóba jöhető lexikaiaspektusosztállyal (teljesítmények, eredmények) való megfeleltetésük látszólag egyszerünek bizonyult, köszönhetően azok általános jegyeinek (dinamikusság, durativitás és mindenekelőtt a behatároltsággal azonosítható telicitás). Az, hogy mind a teljesítmények, mind az eredmények telikusak, arra utal, hogy a magyar nyelvben az akcióminőségként eddig elkülönített jelentéselemek aspektuális tekintetben a behatároltsággal hozhatók összefüggésbe. Ez nagyjából (de nem teljesen) így van a szláv nyelvekben is: a behatároltsághoz Seljakin is jóval több akcióminőséget tudott rendelni, mint a határoltság nélküli nesoversennij vidhez (Seljakin 1987: 69-85). A két aspektuális kategória egymásnak történő megfeleltetését a következőképpen végzem el: előbb Kiefert követve (2006: 150-78) bemutatom a szóban forgó akcióminőséget, közben kiegészítésekkel, megjegyzésekkel látom el az általa leírtakat, végül azonosítom a megfelelő aspektusosztállyal. A 2. táblázatban együtt láthatók a származtatott aspektusfajták, illetve az akcióminőség - lexikai aspektus megfeleltetések.

2. táblázat. Az akcióminőség $\rightarrow$ lexikai aspektus átváltások (összegzés)

\begin{tabular}{|l|l|l|}
\hline & \multicolumn{2}{|c|}{ Származtatott aspektusok } \\
\hline 1. & frekventatív (fel-felnéz) & $\begin{array}{l}\text { állapot (Smith) } \\
\text { imperfektív (Kiefer) }\end{array}$ \\
\hline 2. & iteratív (nyitogat) & $\begin{array}{l}\text { állapot (Smith) } \\
\text { imperfektív (Kiefer) }\end{array}$ \\
\hline 3. & duratív-deminutív (olvasgat, dolgozgat) & cselekvés \\
\hline 4. & delimitatív (elsétálgat) & terminatív cselekvés \\
\hline & \multicolumn{2}{|c|}{ Akcióminőség $\rightarrow$ lexikai aspektus átváltások } \\
\hline & Akcióminőség & Lexikai aspektus \\
\hline 1. & szemelfaktív (megráz) & eredmény (teljesítmény) \\
\hline 2. & ingresszív/inchoatív (elsírja magát) & eredmény \\
\hline 3. & rezultatív (megvarr, lekaszál, megsemmisit) & teljesítmény, eredmény \\
\hline 4. & totális (beken, bejár, kifest) & teljesítmény, eredmény \\
\hline 5. & szaturatív (kisírja magát) & teljesítmény \\
\hline 6. & terminatív (elmond, elénekel) & teljesítmény, eredmény \\
\hline 7. & exhausztív (agyondolgozza magát) & transztelikus teljesítmény \\
\hline 8. & intenzív (agyonporosodik) & transztelikus teljesítmény \\
\hline 9. & szubmerzív (bealszik) & teljesítmény \\
\hline
\end{tabular}




\subsection{Szemelfaktív akcióminőség = eredmény}

Sajnos ismételten egy zavaró terminológiai egybeesésről van szó: az akcióminőségtaxonómiákban az egyszeriséggel azonos, Smith ellenben az eredmények közül kiemelt, hirtelen bekövetkező, állapotváltozással nem járó pillanatnyi eseményeknek (tüsszent, pillant, mozdul) adta ezt az elnevezést. Jelölője a grammatikalizálódott meg-, amely atelikus cselekvésekböl telikus eredményeket hoz létre. Alaki-szemantikai jellemzői alapján az igekötős igék közül ez az igecsoport felelne meg leginkább az akcióminőség-feltételeknek, sőt legközelebb áll a származtatott aspektushoz is, de a képzéssel járó atelikus $\rightarrow$ telikus váltás azonos szintü, az aspektuális alaposztályok közötti cserével is jár, ami kizárja a származtatott aspektusok közül. Kiefernél a bázisigék jelentésének szerves, konstitutív részét képezi a többszöriség, amely az igekötővel egyszeriséggé lesz. Tucatnyi példájánál (2006: 165) én a meg- igekötő funkcióit tárgyaló tanulmányomban nagyságrendileg többet találtam (Szili 2018). Csak néhány a hiányzók közül: megpödör, megráz, megcsavar, megteker, megkapar, meginog, megborsódzik. A nálam tágabb határú csoportosulásban egyaránt vannak olyan bázisigék is, amelyekben az ismétlés morfémával hozzátoldott jelentéselem, tehát származtatott aspektusúnak tekinthetjük öket (ölelget, vakargat, nyomkod, fogdos), illetve olyanok, amelyekben inkorporálódott iteratív képző van (suhogtat, kopogtat, lapogat, simogat, cirógat). Ilyenkor az igekötő az iteratív (egy órán keresztül nyomkodta a hátát), vagy az iteratív mozzanatú duratív atelikus cselekvésekből (tíz percen keresztül kopogtatta a hátát) a szokásos időhatározói teszt alapján teljesítményeket hoz létre: egy óra alatt megnyomkodta a hátát; tíz perc alatt megkopogtatta a hátát. (A hasonló esetek aspektuális viselkedése természetesen további vizsgálatokat kíván.)

\subsection{Ingresszív/inchoatív (kezdő) ,akcióminőség” = eredmény}

Először is kell szólnom a cselekvések, történések, folyamatok kezdetének, a 'V...ni kezd' tartalomnak többféle megtestesüléséröl. A kezdet fogalma magába foglalhatja egyfelől az elözmény nélküli, hirtelen bekövetkező vagy a megelőző szakaszt feltételező eseményszerüségeket is, másfelöl a megkezdődött állapotváltozást leíró folyamatokat (melegedik, zöldül, érik) úgyszintén. (A témáról bővebben Krékits 1977.) Vannak munkák, amelyek külön tárgyalják a kétféle kezdést, az utóbbit az inchoatív, a hirtelen bekövetkező kezdetet pedig az ingresszív jelzővel illetve. Közös jegyük, hogy következményük valamilyen cselekvés vagy valós állapot lesz: elsírta magát $\rightarrow$ sírt: megutál $\rightarrow$ utál. Kiefer elsősorban az előzmény nélküli kezdetekre gondolt akkor, amikor kifejezőeszközét az el... magát szerkezettel azonosította, amely forma képzését a hangadásához kötődő alapigékkel tekinti termékenynek (Kiefer i. m. 169). Ez a termékenység viszonylagos, jegyzem meg, mivel alig tucatnyi hangadást visszaadó igében van jelen ez a tartalom: elbög, elkacag, elkáromkod, elkiált, elnevet, elordit, elröhög, elpityeredik, elsír, elszól, elugat, elvigyorodik. A fel-nek ugyancsak tulajdonít ilyen szerepet, de kevesebb alapigét feltételez mögé: feldübörög, felharsan, felzendül, felzúg. A fel- funkcióit meghatározó dolgozatomban (Szili 
2009) ellenben nagyjából 60 ilyen lexémát találtam, de a meg- is bír kezdő funkcióval az érzelmi cselekvésekre utaló alapigékkel: megsajnál, megutál, megcsömörlik, megszeret. Ezeket Kiefer azért nem tekinti akcióminőségnek sem, mert nem bővíthető osztályt alkotnak, amely kikötést a hangadást kifejező ingresszívumok sem teljesítik. Lexikális osztályukat tekintve eredményigék: nem duratív, dinamikus és telikus jegyekkel rendelkeznek.

\subsection{Rezultatív „akcióminőség” = teljesítmény, eredmény}

Kiefer meghatározása szerint „a cselekvés, folyamat (az ige jelentésében lexikálisan rögzült és aktuális) végpontjára, a cselekvés, folyamat befejeződésére vagy eredményességére utal” (i. m. 170). Meghatározó velejárója, hogy a végpont elérése mindig állapotváltozással jár. A funkciót több igekötő ( $k i, b e, f e l$, le stb.) töltheti be. Képzési szabályát a már ismert módon csak az önálló bázisigékre vonatkoztatja: „minden telikus monomorfemikus igéből képezhető rezultatív akcióminőség, és minden rezultatív akcióminőséget kifejező igének megfelel egy telikus ige" (i. m. 171-2). Az előbbiek (kitakarit, befelhősödik, megvarr) biztos teljesítmények, az azonos tulajdonságú, de alapigével nem rendelkező vagy egyéb módon létrejött alakokat (megsemmisit, megsemmisül, megalakit, megörül, megfilmesit stb.) én az eredmények osztályába helyezem.

A rezultatívumok bennünket leginkább érdeklő aspektuális vonásairól megjegyzi, hogy ez az akcióminőség áll legközelebb a perfektivitáshoz, vagyis a szemléleti aspektus egyik pólusához. Viszonyukat a következőképpen láttatja: az alábbi igepárok első tagja „tiszta” perfektivitást, a második perfektivitást és akcióminőséget jelöl egyszerre: felmos - felmossa a konyhát; megföz - megfözi az ebédet; kitakarít - kitakaritja a lakást; becsomagol - becsomagolja a böröndjét - meggyón - meggyónja a büneit (i. m. 170). Az iménti oppozíciókat feltehetőleg úgy kell érteni, hogy a tárgyas szintagmák által leírt szituációk rezultatív perfektív, az igekötős igékkel megjelenítettek pedig mindössze perfektívek lehetnek. A mérleg nyelve a gyakoriságot tekintve a perfektív rezultatívumok javára billen el szerinte, mert nem minden rezultatív igének (megír, elolvas, felforral, megjavit) van „tiszta perfektív” párja. Tegyük gyorsan hozzá, a túlnyomó többségüknek nincs: a behatároltságnak, a végpont elérésének ugyanis alapfeltétele az, hogy a cél, a végpont kvantizált legyen (névelővel, határozott számjelzős tárggyal stb. legyen ellátva). Az általa „tiszta” perfektívnek mondott formák tehát az igekötős igék használatának atipikus esetei, amikor is a gyakoriság, a szituációs körülmények egyértelmüsítik, szükségtelenné teszik az igekötős ige és a tárgya által alkotott szerkezetből az utóbbit: megetettem, megitattam, elmosogattam. Az elkülönítésüket ritka elöfordulásuk mellett azért is vitathatónak tartom, mert ebben a „tiszta perfektív” előfordulásukban is azonosíthatók a rezultativitással, állapotváltozással.

A rezultatív akcióminőség leggyengébb pontját én mégsem az előbbiekben, hanem abban látom, hogy túl általános definíciója ellenére (végpont elérése, befejeződés, eredményesség, új állapot) kevés alesetet feltételez, pontosan négyet, a totális, szaturatív, terminatív, exhausztív megjelenésmódokat. Mivel az általános gyakor- 
latnak megfelelően ezeket az igeképzés keretében, szemantikai ismérvek, jelesül az alapige és az igekötős jelentésének viszonya alapján határolja el, felmerül a kérdés, valóban „csak” ennyi tartalomban testesül-e meg a befejeződés, eredményesség. Seljakin például öt oldalon keresztül írja le a rezultatívumokat fö- és alfajok tucatjait említve (Seljakin 1987: 73-9). Az általános rezultativitásnak hat altípusa van nála, a rezultativitás speciális megjelenésmódját képviselő mennyiségi rezultativitásnak szintén hat, a mennyiségi-intenzív rezultatívumoknak nyolc, a minőséginek kettő, de ismer rezultatív-határozói alkategóriát is, amelynek ugyancsak két válfaja van. Ez összesen 22 rezultatívumtípus. Noha az orosz és a magyar rendszer nem egyezhet meg teljesen, az igekötők széles kapcsolódási lehetőségeire gondolva jóval több funkciót lehetne találni a magyarban is. Az aspektuális jegyekre összpontosító taxonómia, a teljesítmények és eredmények viszonylag egyszerüen tesztelhető jegyei tehát itt is mentesítenek a szemantikai felosztásból adódó esetlegességektől is (ami nem zárja ki, hogy ne differenciáljunk a kifejezőeszközök funkciói között). Térjünk vissza a négy magyar rezultatívumi ,akcióminőséghez”.

\subsection{Totális „akcióminőség” = teljesítmény, eredmény}

Azt fejezi ki, hogy az igével visszaadott cselekvés vagy történés teljes vagy nagy felületet érint. Kiefer jelölőjének a be- igekötőt tekinti, amely a 'tesz vmit valahova', a 'tesz vmit valamilyenné' jelentésmozzanatot tartalmazó igékkel termékeny (i. m. 172), de felveti, hogy a le- és $k i$ - is rendelkezhet ilyen szereppel, söt szerintem az össze- is (befest, beken, beolajoz, lefest, kifest, összesároz). Ez a tömörülés is jól példázza azt, hogy a képzett ige vonzatkerete nem szükségszerüen egyezik az alapigéjéével. Jelen esetben az iránytárggyal nem, csak a teljes ráhatást biztosító tárggyal dolgozza ki az adott jelentéstartalmat: keni a lakkot a bútorra (a tárgy a mozgást végző trajektor, a lativusi ragos határozó a céltartomány) $\rightarrow$ *bekeni a lakkot a bútorra; keni a bútort lakkal (a határozó tárggyá absztrahálódott, a trajektor eszközhatározói szerepü) $\rightarrow$ bekeni a bútort lakkal. Kiefer a rezultativitás egyik alesetének mondja, én a behatároltsággal járó állapotváltozás egyik változatának, ami teljesítmény- vagy eredményigékben lehet jelen. Az utóbbiakon a jelentésvegyüléssel, metaforizációval keletkezett lexémákat értem: beereszt, befon, bevon, befuttat, bevonódik. És most nézzük az elkülönített négy magyar rezultatív „akcióminőséget”.

\subsection{Szaturatív „akcióminőség” = teljesítmény}

Az igében kifejezett cselekvéssel, folyamattal való betelést jelöli, és a ki-.. magát szerkezethez, illetve a be- igekötőhöz köthető: kialussza magát, kiordítja magát, beszalonnázik (Kiefer i. m. 174-5). A képzés feltétele, hogy az alanynak élőlénynek, az igének duratív és intranzitív cselekvésigének kell lennie, a tárgyasak esetében pedig a tárgyatlan használatot kell figyelembe venni: kiordítja magát. A ki-jelentése több metaforán keresztül is összekapcsolódik képzetünkben az eredeti irányjelentéssel (ez akcióminőséget kizáró jegy lenne), a jelen igecsoportot például AZ EMBERI TEST KONTÉNER - AZ ÉRZÉSEK, A GONDOLATOK, A FIZIKAI ÁLLAPOT TÁRGYAK, AMELYEK 
A TESTKONTÉNERBÖL KIJUTNAK (kiorditja magát, kiírja magát, kigyönyörködi magát, kikúrálja megát). A felsorolt példákban a mozgást végző trajektorok hiányoznak, a forrrástartomány (az emberi test) pedig tárggyá lett: kiordítja magából a gondjait $\rightarrow$ kiordítja magát. Az ellentétes irányú beszalonnázik, besörözik, berúg alakok A TEST KONTÉNER, AZ ÉTEL, ITAL TÁRGY, AMELY A TESTKONTÉNERBE JUT metafora létét bizonyítják. Az első kép abból a tapasztalatunkból táplálkozik, hogy érzéseink, gondolataink végét, semmivé válását a forráshelyükröl, azaz a testünkből való távozásként, onnan történő kikerülésként éljük meg, a második alapja pedig az a mindennapi fizikai tapasztalatunk, hogy a konténerként viselkedő testünk egy idő után megtelik, ha étel, ital kerül bele: tele vagyok, teleeszi magát. Ebben a csoportban nem találtam eredményigét, tehát a teljesítmények osztályát gazdagítják. Két okból is megkérdőjelezhető akcióminőség-besorolásuk: a ki-igekötős változatai nem teljesítik a szintaktikai megkötéseket (*János alussza magát - János kialussza magát), és metaforáik mindkettőt erős szálakkal füzik az irányjelentésekhez.

\subsection{Terminatív „akcióminőség” = teljesítmény, eredmény}

Kiefer definíciója alapján ugyan semmiben sem tér el a perfektív nézöponti aspektustól (i. m. 176), az alapigében foglalt cselekvés, folyamat befejezését jeleníti meg (eldúdol, elénekel), morfológiai jele az el-: elénekel, elfütyül, elrebeg stb. Az alapigék mondást, valamely zenei hanghatást adnak vissza, tárgyi argumentumuk pedig megfelel a cselekvés által végigjárandó útnak, ösvénynek, ezért lehet parafrázisa a 'végig' határozószó: eljátszotta a szonátát = 'végigjátszotta a szonátát'. Az ide sorolható igék teljes körét nézve találunk olyan formákat, amelyeknek alapigéje nem eredeti jelentésében vesz rész a szóképzésben, tehát eredményige: elzúg elszámol, elszámlál: ?János számlálta az előtte álló nehézségeket a hallgatóságának; János elszámlálta az elötte álló nehézségeket a hallgatóságának.

\subsection{Exhausztív „akcióminőség” = transztelikus teljesítmény}

Az utolsó rezultatív akcióminőség. Parafrázisa szerint azt fejezi ki, hogy 'a cselekvést az ágens kifáradásig végzi' (Kiefer i. m. 176). Morfológiai jele az agyon- és tönkre- igekötő: agyontanulja magát, tönkredolgozza magát. Miképpen a példák mutatják, az igekötős változathoz kötelezően a magát visszaható névmás társul. Kiefer produktív képzési módnak mondja: „,minden intranzitív cselekvésigéből (emberi alany esetében) képezhető exhausztív akcióminőség" (i. m. 177). Tegyük hozzá, hogy hipotetikus müveletről van szó, a feltételezett „termékenységet” a szótárak adatai messze nem erösítik meg. A nyelvhasználat változásait rugalmasabban tükröző interneten is utánanéztem az agyon- és tönkre- elötagú igéknek: az agyonbiciklizi magát alakra egyetlen példát találtam, az agyonsétálja magát csak az akcióminőségről szóló dolgozatokban létezik (két tárgyas változatára - agyonsétálta a várost - találtam idézetet, ami talán totális akcióminőség lenne), de hasonló eredménnyel végződött a tönkre-származékai utáni keresésem is: a tönkreírja magát, tönkrebiciklizi magát, tönkretanulja magát szintén csak nyelvészeti példaként léteznek. Vala- 
mivel több adatra leltem a tönkredolgozza magát esetében. Nem minden alap nélkül jelenthető ki tehát, hogy a pillanat ihlette jelentésalkotásnak ez a típusa ritkán éri el a lexikalizáció fokát. Akcióminőség volta nemcsak a képzés hipotetikus termékenysége miatt kérdéses, hanem azért is, mert nem teljesíti azt a feltételt, hogy a képzett ige vonzatkerete és szelekciós jegyei az alapigéhez képest változatlanok maradnak: *János tanulja magát - János agyontanulja magát. Rendszeremben a transztelikus (a feltételezett célon túlnyúló) teljesítmény minősítést kapná. A telicitásnak az orosz aspektusirodalomban (Glovinskaja 1982; Bondarko 1986) ismert két fokozata, a relatív és abszolút telicitás mellé rendszerem egy harmadik létrehozását is szükségessé tette.

\subsection{Intenzív „akcióminőség” = transztelikus teljesítmény}

Elnevezésének megfelelően a cselekvés vagy folyamat túlzott mértékével egyenlő: agyonpirosit, agyonkarcol, agyonszárad. Kiefer szerint jelölöje az agyon- és talán a túl- (túlhangsúlyoz, túlkomplikál). Kapcsolódásukat tranzitív (nem eredménytárgyat kívánó) cselekvésigékkel, valamint önmagukban lezajló folyamatokat viszszaadó igékkel képzeli el (i. m. 177). Megadott (grammatikai) kritériumai azonban túl tágak, határok nélküli igecsoportokat eredményeznek: az egyértelmü, hogy az eredménytárgyas igék előtt - amelyeknek pontos körét nem ismerjük - helytelen mondatokat kapunk velük (*agyonépíti a házat; *agyonírja a leckét), viszont a nem eredménytárgyas igék előtt széles családjának sem mindegyik tagjához járulhatnak: *agyonvárja a barátját, *agyonmondja a történetet. Kiefer magyarázata szerinte azért nem lehetséges az igekötő használata ezeknél a formáknál, mert az alapigével jelölt cselekvéseknek nincs hatásuk a tárgyukra. Helytelennek tartott példáinál ennek ellenkezőjét érzem: *agyonolvassa a könyvet, *agyonhallgatja a szonátát, *agyonnézi a filmet.

Szerintem lehetnének akár rezultatívumok is: Seljakin például a mennyiségi rezultativitás mértéken felüliséget kifejező típusába (cezmerno normativnij sposob dejstvija) helyez hasonló igéket idézett tanulmányában (Seljakin 1987: 78). Aspektuális osztályukat tekintve teljesítmények, de mivel a feltételezett kulminációs ponton túllépő eseményekkel azonosíthatók, a transztelikus jelzővel választottam el őket az abszolút telikus társaiktól. Formai megjelenítőjének tartom még az el-t is: elázik, elfó, elhízik. Transztelikus aspektuális jegyük azt feltételezi, hogy van egy, a kulminációs pont elérését tükröző igekötős lexéma, amely az abszolút telikus jegy hordozója, hiszen a szóban forgó származékok ezekhez viszonyítva nyerik el túlzó tartalmukat: kirúzsozza magát - agyonrúzsozza magát; megázik-elázik; megszárad - agyonszárad; felcicomáz - agyoncicomáz, megföz - elföz.

\subsection{Szubmerzív „akcióminőség” = teljesítmény}

Az idézőjel ebben a típusban kétszeresen indokolt, Kiefer is kérdőjeles új fejleménynek tartja a bealszik, berévül, besír, behisztizik, betáncol és hasonló képzéseket, amelyek azt fejezik ki, hogy ,az az alannyal jelölt személy 'valamilyen intenzív/ 
felfokozott lelki vagy tudati állapotba kerül és abban elmerül'” (i. m. 179). A képzést termékenynek tartja az intranzitív cselekvésigékkel (táncol, smárol) és a tudati állapotigékkel (alszik, szomorkodik). Internetes keresésem alapján ismét csak azt kell mondanom, hogy inkább rétegnyelvi, a szleng szókincsébe tartozó származékok, amelyek mintha eltünőben lennének ebböl a nyelvi rétegböl is. Noha a nyelvész tiszte nem az ítélkezés, véleményalkotás, őszintén megvallva nem szomorkodnék be elvesztésük miatt.

\section{6. Összegzés}

Dolgozatom fő célja az akcióminőség fogalmának, osztályozásának ellentmondásait elötérbe helyezve annak bizonyítása volt, hogy az akcióminőség és az aspektuális osztályok esetében két eltérő szempontrendszert alkalmazó klasszifikációról van szó: az akcióminőségen nagyrészt szemantikai ismérvekkel jellemezhető, de az igeképzésen belül elhatárolt tulajdonságegyüttest ért a szakirodalom, míg a lexikai aspektus az eseményszerüségek időbeliségével szorosan összefüggő jegyek, aspektuális ismérvek szerint osztályoz. Az akcióminőség $\rightarrow$ lexikai aspektus megfeleltetés első lépéseként a „szük” akcióminőség-értelmezés kritériumainak számonkérésével a 13, magyar nyelvre megállapított akcióminőség-fajtából leválasztottam a Smithféle felosztás származtatott aspektus kategóriájába illőket, az iteratív, frekventatív, duratív-deminutív, delimitatív formákat. Az igekötős igékkel kifejezett akcióminőség-típusok és az alapfogalmuk feltételeinek szembesítése több kérdéses jelenségre hívta fel a figyelmet: az egyes típusok nem felelnek meg maradéktalanul a szük akcióminőség-értelmezés követelményeinek; taxonómiájuk nagyrészt szemantikai szempontokon alapul, és nem aspektuális tulajdonságokon, illetve nem létező határvonalat húz az igeképzésben betöltött és ,akcióminőség-képző” funkciói között. Mindezekkel ellentétben a lexikaiaspektus-osztályokba való integrálásuk problémamentesnek bizonyult. A dolgozat pozitív hozadéka az egyes származtatott aspektusok, így az iteratív, a delimitatív aspektus jellemzőinek pontosítása, a telicitás fokozatainak újabb, a transztelikus változattal történő bővítése, valamint az ismétlés, mozzanatosság kifejezésének differenciáltabb meghatározása.

Szili Katalin

egyetemi docens

Eperjesi Egyetem, Magyar Nyelv és Kultúra Intézete https://orcid.org/0000-0003-4562-3669 


\section{SZAKIRODALOM}

Bondarko, Alexander, V. 1986. Semantika predela. Voprosy jazykoznanija 1: 14-25.

Glovinskaja, Marija J. 1982. Szemanticheskije tipy vidovih protivopostavlenij russzkogo glagola. Nauka, Moszkva.

Kiefer Ferenc 2006. Aspektus és akcióminöség különös tekintettel a magyar nyelvre. Akadémiai Kiadó, Budapest.

Krékits József 1977. Az ingressziv akcióminőségü orosz igék és magyar nyelvi megfelelöik. A Juhász Gyula Tanárképzö Föiskola Tudományos Közleményei 1: 95-106.

Németh Boglárka 2012. Az aspektus a magyar nyelvben. Tinta Könyvkiadó, Budapest.

Papp Ferenc 1969. A magyar nyelv szóvégmutató szótára. Akadémiai Kiadó, Budapest.

Seljakin, M. A. 1987. Sposobi dejstvija v polje limitativnosti. In: A. V. Bondarko (ed). Teorija funkcionalnoj grammatiki. Nauka, Leningrad, 63-85.

Szili Katalin 2009. A fel, le és egyéb igekötős igék formai-szemantikai viszonyának kérdéséhez. Magyar Nyelv 105: 175-88.

Szili Katalin 2018. A meg- funkcióiról másképpen I-II. (A meg- mint lexikaiaspektus-képző) Magyar Nyelvör 142: 170-86; 428-51.

\section{SUMMARY}

\section{Aktionsart or lexical aspect? Part II (Issues raised by Hungarian Aktionsarts)}

\section{Szili, Katalin}

The paper tries to clarify some terminological, content-related, formal, and classificational issues related to two concepts pertaining to the aspectual characteristics of verbs, Aktionsart vs. situational/lexical aspect. The discussion focuses on the narrower category of the two, Aktionsarts; in particular, on problems and paradoxes of their classification. The idea is to integrate Aktionsarts into lexical aspect, a concept better suited to the determination of the aspectual properties of verbs. The new classification differentiates between Smith's derived aspects, the iterative, frequentative, durative/diminutive, and delimitative aspects, and the kinds of Aktionsarts expressed by prefixed accomplishment and achievement verbs. Such integration of Aktionsarts into the category of lexical aspect is underpinned by the following arguments: the individual types of Aktionsarts do not fully comply with the criteria of being an Aktionsart; their taxonomy is mainly based on semantic considerations, rather than on their aspectual properties; and the dividing line often drawn between the roles of preverbs in word formation and in forming Aktionsarts is a non-existent one.

Keywords: lexical aspect, aspectual classes, Aktionsart, derived aspect 